\title{
Clarification of The Corrosion Inhibition of Mild \\ Steel in Hydrochloric Acid Solutions via Cetyltrimethyl Ammonium Bromide Inhibitor
}

\author{
Z. Abdel Hamid, A. M. Atia*, A. M. Helal" and H. E. Megahed* \\ Corrosion Control and Surface Protection Laboratory, Central \\ Metallurgical R\&D Institute, CMRDI, Helwan and "Department of \\ Chemistry, Faculty of Science, Benha University, Benha, Egypt.
}

\begin{abstract}
CTYLTRIMETHYL ammonium bromide (CTAB) was investigated as corrosion inhibitors of mild steel in 0.1 and $0.5 \mathrm{M} \mathrm{HCl}$ solutions using weight loss, Tafel polarization and electrochemical impedance spectroscopy techniques. The experimental results showed that the inhibition efficiency increases with increasing of CTAB concentrations but decreases with increasing temperature. The adsorption of CTAB on the mild steel surface obeyed the Langmuir adsorption isotherm. Potentiodynamic polarization curves showed that CTAB acted as a cathodic inhibition predominantly in hydrochloric acid. This was supported by the impedance measurements which showed a change in the charge transfer resistance $\left(\mathrm{R}_{\mathrm{ct}}\right)$ and double layer capacitance $\left(\mathrm{C}_{\mathrm{dl}}\right)$ indicating adsorption of CTAB on the mild steel surface. Thermodynamic parameters were also calculated to know the mechanism of the inhibition. The thermodynamic functions of the adsorption processes were calculated from the weight loss and effect of temperature data and were used to analyze the inhibitor adsorption mechanism. The thermodynamic parameters indicate that physical adsorption and chemisorptions of the inhibitor on the metal surface may occur.
\end{abstract}

Keyword: Cetyltrimethyl ammonium bromide (CTAB), Mild steel, Corrosion inhibitor, Langmuir adsorption isotherm, Potentiodynamic polarization and Free energy.

The carbon steel is used as essential part in the manufacturing of installations used in the petroleum and other industries. Corrosion is a common phenomenon in industries, and it attracts considerable amount of interest because of its hazardous nature on metals ${ }^{(1)}$. Acids are widely used in industries such as pickling, cleaning, descaling, oil-well acid in oil recovery, and the petrochemical processes, which leads to corrosive attack of metals ${ }^{(2-4)}$. So, the use of inhibitors is one of the most practical methods to reduce the corrosive attack on metallic materials ${ }^{(5-6)}$. The selection of appropriate inhibitors mainly depends on the type of acid, its concentration and temperature, the presence of dissolved organic and/or inorganic substances and on the type of metallic material exposed to the action of the acidic solution. Also, cost, toxicity, and availability are important factors in the selection and utilization of these inhibitors. Most of the inhibitors are organic molecules $^{(7)}$; however, inorganic molecules ${ }^{(8)}$ and polymeric materials ${ }^{(9)}$ are also 
used. Organic compounds have been widely used as corrosion inhibitors for metals in acidic media ${ }^{(10-15)}$. The organic inhibitors decrease the corrosion rate by adsorbing on the metal surface and blocking the active sites by displacing water molecules and form a compact barrier film on the metal surface ${ }^{(16,17)}$. It has been reported that quaternary ammonium compounds (surfactants) are important as inhibitor additives in hydrochloric acid. Many mechanisms have been proposed for the inhibition of metal corrosion by organic inhibitors ${ }^{(18-20)}$.

The present work was undertaken to investigate the corrosion inhibition behavior of (CTAB) on mild steel in 0.1 and $0.5 \mathrm{M} \mathrm{HCl}$ solutions. The efficiency of this additive will be discussed in relation to the effect of the corresponding structure, atom of active center and substituted halide $(\mathrm{Br})$, in attempting to explain the mechanism whereby corrosion resistance is improved. For this purpose, the behavior of carbon steel in $\mathrm{HCl}$ acid solutions in the absence and presence of the inhibitor was studied using weight loss, Tafel polarization and electrochemical impedance spectroscopy (EIS) techniques.

\section{Weight loss technique}

\section{Experimental}

Experiments were performed using low carbon steel with the following chemical composition (wt.\%):C: 0.06, Mn: 0.7, Si: 0.06, S: 0.012, P: 0.001, V: 0.005 , Ni: $0.015, \mathrm{Cr}: 0.004, \mathrm{Mo}: 0.002, \mathrm{Cu}: 0.02$ and iron is the remainder with size $(2 \mathrm{~cm} \times 4 \mathrm{~cm} \times 0.3 \mathrm{~cm})$ for the measurement of weight loss. For all the experiments, the surface pre-treatment was carried out by grinding with emery paper $\mathrm{SiC}$ (grades 400, 800, 1000 and 1200), rinsed with distilled water, degreased in alkaline degreaser immersion for $5 \mathrm{~min}$ at $70^{\circ} \mathrm{C}$ and finally dried using a stream of air at room temperature. The acidic solutions 0.1 and $0.5 \mathrm{M}$ $\mathrm{HCl}$ were prepared by dilution of analytical grade $37 \% \mathrm{HCl}$ with distilled water. The inhibitor used, namely CTAB is a surfactant $\left.\left(\mathrm{C}_{16} \mathrm{H}_{33}\right) \mathrm{N}\left(\mathrm{CH}_{3}\right)_{3} \mathrm{Br}\right)$. All solutions were prepared using bi-distilled water. IEs for different concentrations of the inhibitor were calculated from weight loss values in the absence and presence of the inhibitor at different temperatures. The effect of temperature 20 $40^{\circ} \mathrm{C}$ on the performance of the inhibitor and the effectiveness of the inhibitor at higher acid strength were also studied. The samples were immersed in hanging positions in 0.1 or $0.5 \mathrm{M} \mathrm{HCl}$ solution containing different concentrations of inhibitors for $24 \mathrm{hr}$. Samples were weighed before and after immersion and weight differences were determined. The degree of surface coverage $(\theta)$ and percentage inhibition efficiency (IE \%) were calculated from the following equations:

Surface Coverage $(\theta)=\mathrm{W}_{0}-\mathrm{W} / \mathrm{W}_{0} \ldots \ldots \ldots \ldots \ldots \ldots$
Inhibition Efficiency $(\mathrm{IE} \%)=\left(\mathrm{W}_{0}-\mathrm{W} / \mathrm{W}_{0}\right) \mathrm{X} 100 \ldots$

where $\mathrm{W}_{0}$ and $\mathrm{W}$ are the weight loss of mild steel without and with the inhibitor, respectively. It was assumed that the surface was saturated with adsorbed inhibitor molecules, that is $\theta=1$.

Egypt. J. Chem. 57, No. 5,6 (2014) 
The corrosion rate "CR" was calculated from the following equation:

$$
\mathrm{CR}=\frac{m_{1}-m_{2}}{s . t}
$$

where $\mathrm{m} 1$ and $\mathrm{m}_{2}$ are the weights of the specimen before and after in $\mathrm{mg}, \mathrm{S}\left(\mathrm{cm}^{2}\right)$ is the total area of the specimen and $\mathrm{t}(\mathrm{h})$ is the immersion time. The weight loss data were made after $24 \mathrm{hr}$ of immersion.

\section{Potentiodynamic polarization measurements}

The sheet cut of the same composition embedded in cell with an exposed area of $1 \mathrm{~cm}^{2}$ was used for the electrochemical studies. Electrochemical measurements were carried out in a conventional three - electrode cell; platinum sheet and saturated calomel electrode (SCE) was used as counter and reference electrodes, respectively. The potentiodynamic current - potential curves were recorded by changing the electrode potential automatically from -0.250 to $0.250 \mathrm{mV}$ with a scan rate $10 \mathrm{mVs}^{-1}$ using Iviumstat instrument (supplied by Ivium technologies, Eindhoven, Netherlands). The Ivium stat software can be used to control Ivium stat instrument, by means of a personal computer (PC). The experiments were measured after $24 \mathrm{hr}$ of immersion in the testing solution (no deaeration, no stirring).The mild steel surface was exposed to various concentrations of CTAB in $100 \mathrm{ml}$ of 0.1 and $0.5 \mathrm{M} \mathrm{HCl}$ at different temperatures.

Tafel plots were illustrated by plotting E Vs $\log$ I. Corrosion potential $\left(\mathrm{E}_{\text {corr }}\right)$, corrosion current density $\left(I_{\text {corr }}\right)$, cathodic and anodic slopes $\left(\beta_{\mathrm{c}}\right.$ and $\left.\beta_{\mathrm{a}}\right)$ were calculated according to known procedures. The inhibition efficiency (IE\%) was calculated using the following equation for Inhibition Efficiency:

$$
\mathrm{IE} \%=\left(\mathrm{I}_{0}-\mathrm{I} / \mathrm{I}_{0}\right) \times 100
$$

where $\mathrm{I}_{0}$ and $\mathrm{I}$ are the corrosion current density without and with the inhibitor, respectively.

\section{Electrochemical impedance measurements}

The EIS spectra were recorded at open circuit potential (OCP) after immersion of the electrode in the test solution. EIS tests were carried out in the frequency range from 0.1 to $10000 \mathrm{~Hz}$ using an amplitude of $20 \mathrm{mV}$ and $10 \mathrm{mV}$ peak to peak with an AC signal. The impedance diagrams were plotted in the Nyquist representation. Charge transfer resistance $\left(R_{c t}\right)$ values were obtained by subtracting the high-frequency impedance. The IEs were calculated from the following equation:

$$
\% \mathrm{IE}=\left(\mathrm{R}_{\mathrm{ct}}-\mathrm{R}_{\mathrm{ct}} / \mathrm{R}_{\mathrm{ct}}\right) \times 100
$$

where $\mathrm{R}_{\mathrm{ct}}$ and $\mathrm{R}_{\mathrm{ct}}$ are the corrosion current of mild steel with and without inhibitor, respectively. 


\section{Results and Discussion}

\section{Weight loss measurements}

The corrosion behavior of a metal in aqueous environment is characterized by measuring the weight loss of a specimen after exposure to corrosive media. The weight loss method is usually preferred because the quantity measured is directly related to the extent of corrosion and does not rely on any assumptions about reactions occurring during corrosion. The weight loss technique was employed as the chemical testing technique to evaluate the influence of inhibitor compounds on the corrosion of low carbon steel in $0.1 \mathrm{M}$ and $0.5 \mathrm{M} \mathrm{HCl}$ solution at different temperatures $20,25,30,35,40{ }^{\circ} \mathrm{C}$.

Effect of concentration and temperature on the corrosion rate and efficiency

The results of the gravimetric determination of carbon steel in different concentrations acidic medium $(0.1$ and $0.5 \mathrm{M} \mathrm{HCl})$ operated at different temperature such as $\mathrm{CR}$ and IEs without and with addition of various CTAB concentration inhibitor are summarized in Tables $1 \& 2$ and Fig. 1\&2, respectively. As shown from these tables and figures, by increasing the temperature, the corrosion rate of carbon steel is increased at the same concentration, a remarkable decrease in the carbon steel corrosion rate was observed with the addition of increasing amount of inhibitors at each studied temperature. This means that the presence of CTAB inhibitor retards the corrosion of carbon steel in $0.1 \mathrm{M}$ and $0.5 \mathrm{M} \mathrm{HCl}$ solution at different temperatures $\left(20-40{ }^{\circ} \mathrm{C}\right)$. Moreover, the results reveal that the $\mathrm{CR}$ of carbon steel was reduced in the presence of the inhibitor compared to the blank acid solution. Also, corrosion rate is seen to increase with temperature rise both in the absence and in the presence of the inhibitor. The temperature increases the rate of all electrochemical processes as well influences adsorption equilibrium and kinetics. It can be seen that the corrosion rate increases and efficiency decreases with temperature in the absence and presence of inhibitor. Adsorption and desorption of inhibitor molecules continuously occur at the metal surface and an equilibrium exists between two processes at a particular temperature. With increase of temperature, the equilibrium between adsorption and desorption processes is shifted to a higher desorption rate than adsorption until equilibrium is again established at a different value of equilibrium constant. It explains the lower inhibition efficiency at higher temperature.

Egypt. J. Chem. 57, No. 5,6 (2014) 
TABLE 1. Corrosion rates of low carbon steel specimen in $0.1 \mathrm{M} \mathrm{HCl}$ in the absence and presence of different concentrations of CTAB at different temperatures.

\begin{tabular}{|l|c|c|c|c|c|c|}
\hline \multirow{2}{*}{$\mathbf{T}(\mathbf{K})$} & \multicolumn{7}{|c|}{ Corr. Rate $\left(\mathbf{m g . c m}^{-2} \mathbf{. h}^{-1}\right)$} \\
\cline { 2 - 7 } $\mathbf{C}_{\text {inh }}$ & $\mathbf{0 ~ p p m}$ & $\mathbf{3} \mathbf{~ p p m}$ & $\mathbf{4} \mathbf{~ p p m}$ & $\mathbf{5} \mathbf{~ p p m}$ & $\mathbf{6} \mathbf{~ p p m}$ & $\mathbf{7} \mathbf{~ p p m}$ \\
\hline 293 & 0.159879 & 0.048844 & 0.037631 & 0.026968 & 0.025523 & 0.018987 \\
\hline 298 & 0.161048 & 0.060883 & 0.046161 & 0.037149 & 0.033434 & 0.025385 \\
\hline 303 & 0.162287 & 0.079458 & 0.060195 & 0.053866 & 0.049807 & 0.036874 \\
\hline 308 & 0.163387 & 0.092529 & 0.07705 & 0.068932 & 0.05992 & 0.050633 \\
\hline 313 & 0.164626 & 0.104018 & 0.097895 & 0.088539 & 0.078013 & 0.069345 \\
\hline
\end{tabular}

TABLE 2. Corrosion rates of low carbon steel specimen in $0.5 \mathrm{M} \mathrm{HCl}$ in the absence and presence of different concentrations of CTAB at different temperatures.

\begin{tabular}{|l|c|c|c|c|c|c|}
\hline $\mathbf{T}(\mathbf{K}) /$ & \multicolumn{7}{|c|}{ Corr. Rate $\left(\mathbf{m g . c m}^{\mathbf{2}} \mathbf{. h}^{\mathbf{- 1}}\right)$} \\
\cline { 2 - 7 } & $\mathbf{0} \mathbf{~ p p m}$ & $\mathbf{5} \mathbf{~ p p m}$ & $\mathbf{1 0} \mathbf{~ p p m}$ & $\mathbf{1 5} \mathbf{~ p p m}$ & $\mathbf{2 0} \mathbf{~ p p m}$ & $\mathbf{2 5} \mathbf{~ p p m}$ \\
\hline $\mathbf{C}_{\mathbf{i n h}}$ & & & & & & \\
\hline 293 & 0.647083 & 0.18437 & 0.133187 & 0.098445 & 0.067006 & 0.043822 \\
\hline 298 & 0.672812 & 0.25454 & 0.194001 & 0.158916 & 0.133462 & 0.098376 \\
\hline 303 & 0.74484 & 0.383462 & 0.313773 & 0.282058 & 0.232595 & 0.196753 \\
\hline 308 & 0.785636 & 0.500826 & 0.411392 & 0.35842 & 0.306824 & 0.272427 \\
\hline 313 & 0.826912 & 0.613718 & 0.54052 & 0.454871 & 0.395363 & 0.356976 \\
\hline
\end{tabular}

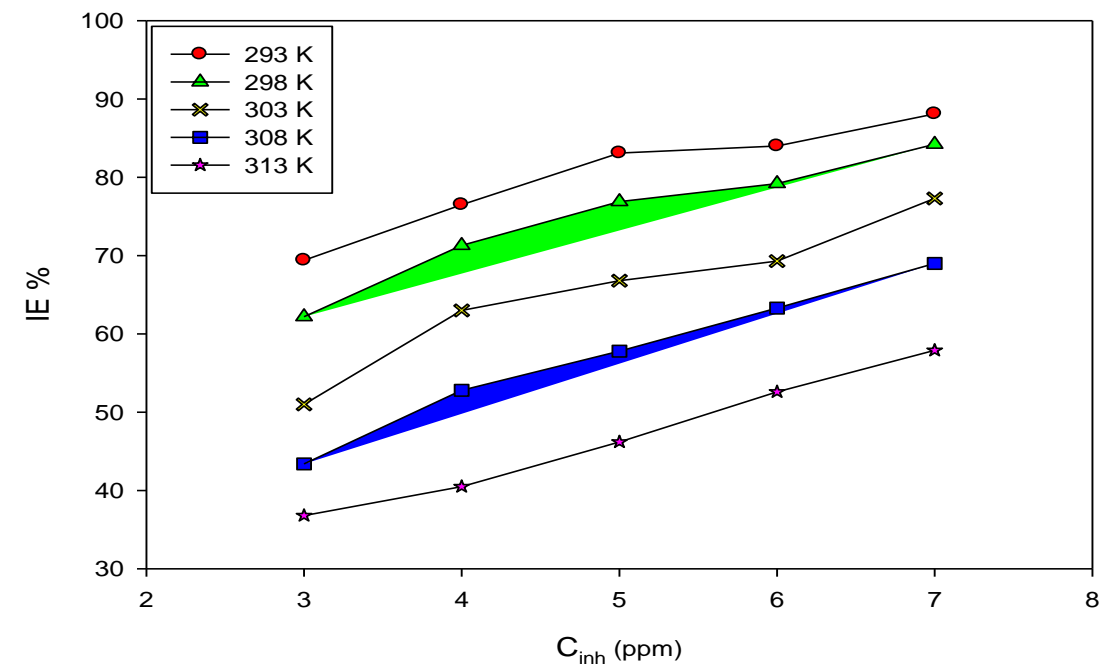

Fig. 1. Variation of IE (\%) with CTAB concentration at different temperatures in 0.1M HCl solution. 


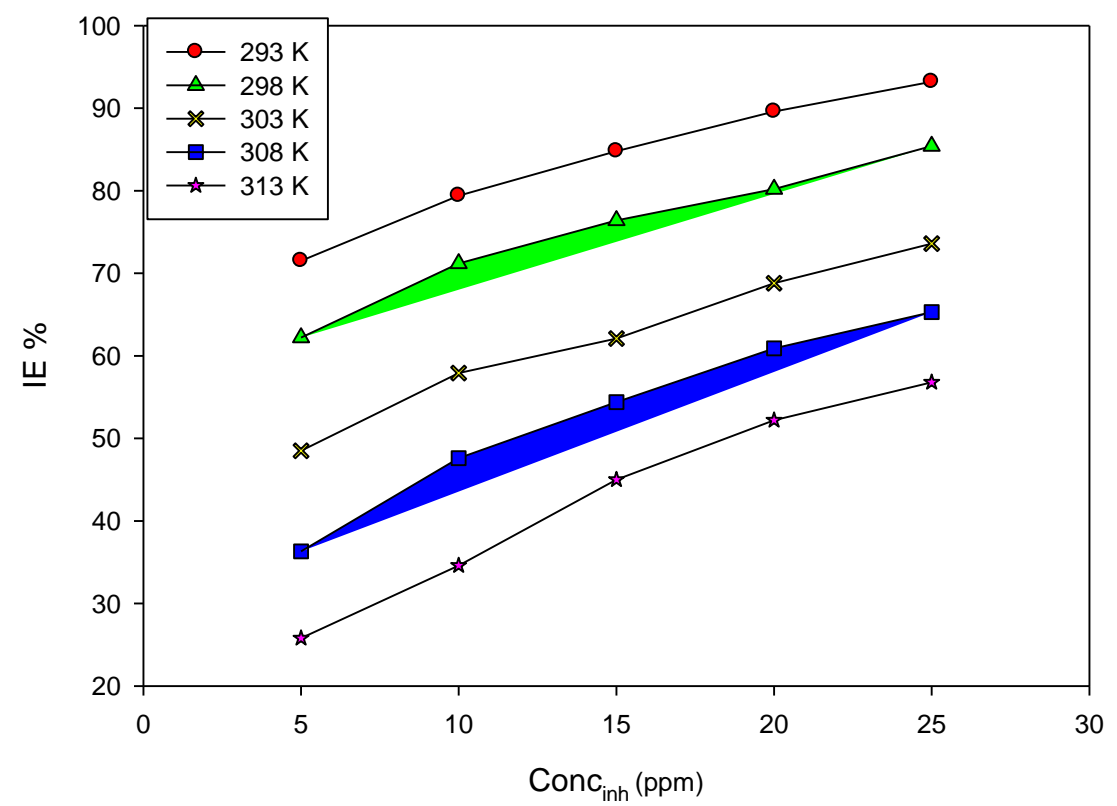

Fig. 2. Variation of IE (\%) with CTAB concentration at different temperatures in 0.5 $\mathrm{MHCl}$ solution.

It is observed that \% IE increases with increasing the concentration of inhibitor and at the same time decreases with increasing temperature in different $\mathrm{HCl}$ concentration solutions. It is illustrated that $\mathrm{CTAB}$ has good \% IE, as the concentration of $\mathrm{CTAB}$ increases the inhibition efficiency increases, i.e. $3 \mathrm{ppm}$ of CTAB has $I E=69.4 \%$ while7 ppm of CTAB has $I E=88.1 \%$ operated at 293 $\mathrm{K}$. Increase in inhibition efficiency with increase in the concentration is suggestive of the adsorption of the inhibitor onto the mild steel surface. It was also reported that the inhibition of $\mathrm{CTAB}$ in $0.5 \mathrm{M} \mathrm{HCl}$ was not good with loss inhibitor concentration used with $0.1 \mathrm{~m} \mathrm{HCl}$ solution, so we used high inhibitor concentration up to $25 \mathrm{ppm}$ due to increasing the CTAB concentration more than $25 \mathrm{ppm}$ probably has the same \%IE. These results indicated that the concentration of $\mathrm{HCl}$ plays an important role in the inhibition efficiency.

In examining the effect of temperature on the apparent activation energies $\left(E_{a}\right)$ were calculated from the Arrhenius equation to illustrate the nature of the adsorption $^{(21)}$ :

$$
\log \left(\mathrm{CR}_{2} / \mathrm{CR}_{1}\right)=\mathrm{E}_{\mathrm{a}} / 2.303 \mathrm{R}\left(1 / \mathrm{T}_{1}-1 / \mathrm{T}_{2}\right)
$$

where $C_{1}$ and $C R_{2}$ are the corrosion rates at temperature $T_{1}(303 K)$ and $T_{2}$ $(313 \mathrm{~K})$, respectively, and $\mathrm{R}$ is the molar gas constant. The calculated values for $\mathrm{E}_{\mathrm{a}}$ parameter are given in Table 3. The values of $\mathrm{E}_{\mathrm{a}}$ are: 11.5, 75.8, 126.2,

Egypt. J. Chem. 57, No. 5,6 (2014) 
$137.5 \mathrm{~kJ} / \mathrm{mol}$ for the $0.1 \mathrm{M} \mathrm{HCl}$ and inhibitor concentrations $0,3,5,7 \mathrm{ppm}$, respectively. While the $\mathrm{E}_{\mathrm{a}}$ are: $29.9,127,183.8,247 \mathrm{~kJ} / \mathrm{mol}$ for the $0.5 \mathrm{M} \mathrm{HCl}$ and $0,5,15,25 \mathrm{ppm}$ inhibitor concentrations, respectively. Generally, a corrosion inhibitor is a substance that increases the activation energy of the corrosion process and this is clear from the obtained values of $\mathrm{E}_{\mathrm{a}}$ in different concentration acid solutions in the presence of the investigated inhibitor. This means that the energy barrier for the corrosion reaction increases in the presence of the inhibitor, where the corrosion reaction will be further pushed to surface sites that are characterized by higher values of $E_{a}$. This indicates that carbon steel corrosion occurs at the uncovered part of its surface. The value of $E_{a}$ for the investigated inhibitors increases according to the inhibitor concentration increase. This order is the same as that of the inhibition efficiency. Increased $\mathrm{E}_{\mathrm{a}}$ in inhibited solutions compared to the blank suggests that the inhibitor is physically adsorbed on the corroding metal surface while either unchanged or lower $E_{a}$ in the presence of inhibitor suggest chemisorptions $^{(22)}$. The results reveal that the adsorption is physical adsorption.

TABLE 3. Calculated values of activation energy $\left(E_{a}\right)$ for low carbon steel in 0.1 and $0.5 \mathrm{M} \mathrm{HCl}$ in the absence and presence of inhibitor.

\begin{tabular}{|c|c|}
\hline Concentration of Inhibitor, ppm & $\begin{array}{l}\mathrm{E}_{\mathrm{a}}\left(\mathrm{KJ} \mathrm{Jmol}^{-1}\right) \\
\text { In } 0.1 \mathrm{M} \mathrm{HCl}^{2}\end{array}$ \\
\hline Blank & 11.5 \\
\hline 3 & 75.8 \\
\hline 5 & 126.2 \\
\hline 7 & 137.5 \\
\hline Concentration of Inhibitor, ppm & $\begin{array}{l}\text { Ea }\left(\mathrm{KJmol}^{-1}\right) \\
\text { In } 0.5 \mathrm{M} \mathrm{HCl}^{2}\end{array}$ \\
\hline Blank & 29.9 \\
\hline 5 & 127 \\
\hline 15 & 183.8 \\
\hline 25 & 247 \\
\hline
\end{tabular}

\section{Polarization measurement}

Anodic and cathodic polarization curves were recorded to obtain information about the action of the inhibitor on the partial corrosion processes. Figures 3 and 4 show the polarization curves measured on carbon steel electrodes in each of 0.1 and $0.5 \mathrm{M} \mathrm{HCl}$ solutions at $20{ }^{\circ} \mathrm{C}$ in the absence and in presence of CTAB inhibitor. The electrochemical parameters, such as current density $\left(\mathrm{i}_{\text {corr }}\right)$, anodic $\left(b_{a}\right)$ and cathodic $\left(b_{c}\right)$ slopes, were obtained by Tafel extrapolation at the corrosion potential $\left(\mathrm{E}_{\text {corr }}\right)$ and are reported in Table 4 . It is observed that the current density of the anodic and cathodic branch is displaced towards lower values. This displacement is more evident with the increase in concentration of the corrosion inhibitor. 
It can be seen from the results that $\mathrm{I}_{\text {corr }}$ values decrease with increasing the CTAB concentration range in 0.1 and $0.5 \mathrm{M} \mathrm{HCl}$ solutions. Maximum reduction of $\mathrm{I}_{\text {corr }}$ for $\mathrm{CTAB}$ is obtained at $7 \mathrm{ppm}$ concentration in $0.1 \mathrm{M} \mathrm{HCl}$ and $25 \mathrm{ppm}$ concentration in $0.5 \mathrm{M} \mathrm{HCl}$. It is also observed that the slopes do not display an order with the inhibitor concentration; this feature indicates that corrosion inhibitors have no effect on both hydrogen evolution and iron dissolution reactions, it appears that inhibition occurred by a blocking mechanism on the available metal spaces ${ }^{(23)}$. Moreover, the corrosion potential in the presence of inhibitor displayed small fluctuations around the corrosion potential of the solution in the absence of inhibitor and it tends to slightly change towards the negative direction (Table 4). These results indicate that the presence of CTAB compound inhibited iron oxidation and the hydrogen evolution reactions; consequently this compound can be classified as a mixed type corrosion inhibitor $^{(23)}$.

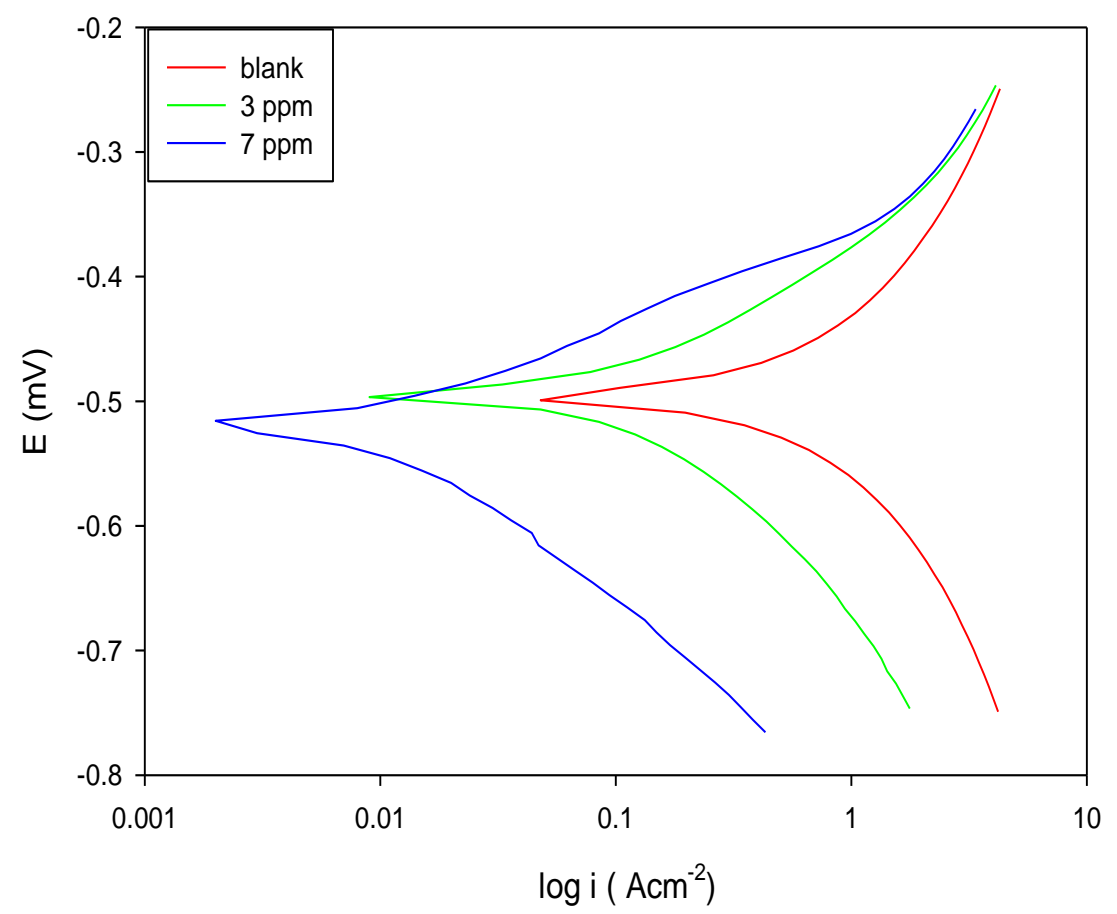

Fig. 3. The potentiodynamic polarization curves of carbon steel in $0.1 \mathrm{M} \mathrm{HCl}$ with and without different concentrations of CTAB operated at $20^{\circ} \mathrm{C}$.

Egypt. J. Chem. 57, No. 5,6 (2014) 


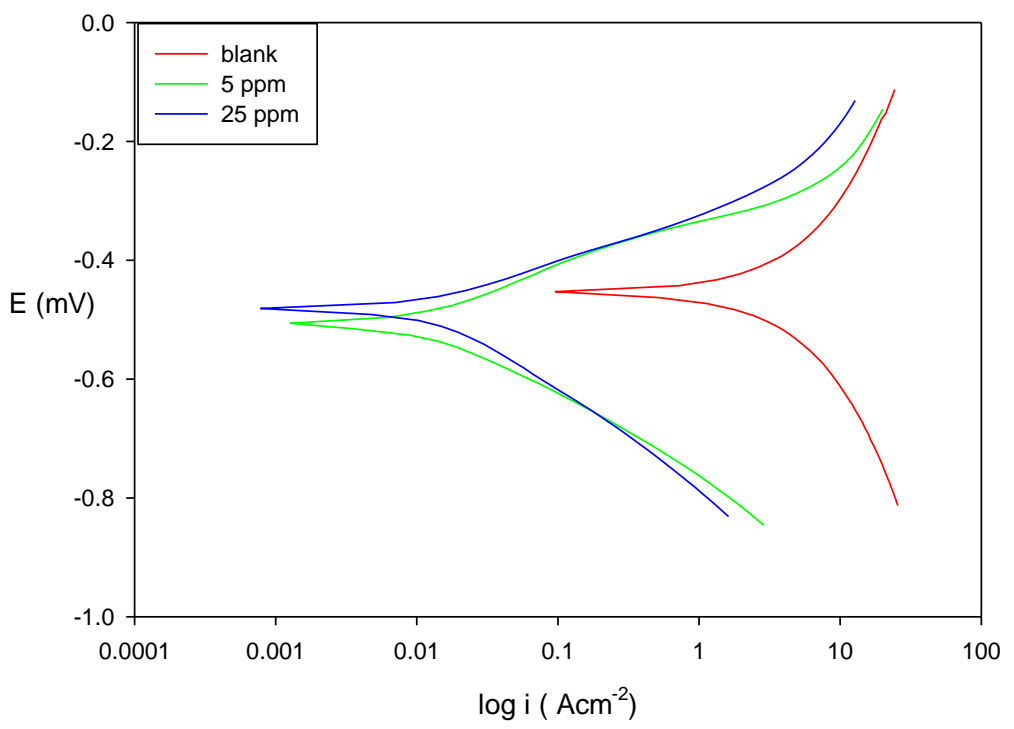

Fig. 4. The potentiodynamic polarization curves of carbon steel in $0.5 \mathrm{M} \mathrm{HCl}$ with and without different concentrations of CTAB operated at $20{ }^{\circ} \mathrm{C}$.

TABLE 4. Variation of polarization parameters for low carbon steel in $0.1 \mathrm{M}$ and $0.5 \mathrm{M}$ $\mathrm{HCl}$ solutions at $20 \mathrm{C}^{\circ}$ with different CTAB concentration inhibitor.

\begin{tabular}{|c|c|c|c|c|c|c|}
\hline & $\begin{array}{c}\text { Conc } \\
\mathbf{p p m}\end{array}$ & Ecorr, $\mathrm{mV}$ & $\begin{array}{c}\text { icorr, } \\
\mathrm{mA} \mathrm{cm}^{-2}\end{array}$ & $\begin{array}{c}\text { bc, } \\
\mathbf{m V ~ d e c}^{-1}\end{array}$ & $\begin{array}{c}\text { ba, } \\
\mathbf{m V ~ d e c}^{-1}\end{array}$ & IE \% \\
\cline { 2 - 7 } At 0.1 M & 0 & -509 & 1439 & 226 & 248 & \\
\cline { 2 - 7 } $\mathbf{H C l}$ & 3 & -506 & 475 & 203 & 242 & 67.00 \\
\cline { 2 - 7 } & 7 & -525 & 133 & 180 & 240 & 90.70 \\
\hline \multirow{3}{*}{$\begin{array}{c}\text { At 0.5 M } \\
\mathbf{H C l}\end{array}$} & 0 & -473 & 4104 & 235 & 257 & \\
\cline { 2 - 8 } & 25 & -506 & 1062 & 175 & 244 & 74.10 \\
\cline { 2 - 8 } & & -491 & 249 & 168 & 234 & 93.90 \\
\hline
\end{tabular}

Electrochemical impedance spectroscopy (EIS)

The corrosion behavior of carbon steel in 0.1 and $0.5 \mathrm{M} \mathrm{HCl}$ solutions in the absence and presence of different concentrations of inhibitor was investigated by AC impedance spectra technique (EIS) at $25{ }^{\circ} \mathrm{C}$ as shown in Fig. $5 \& 6$ (Nyquist plots) and in Fig. $7 \& 8$ (Bode plots). The impedance $\log (Z / \Omega)$ values derived from Bode plots are also given in Tables 5\&6. Using Ivium software, the impedance spectra of the different Nyquist plots were analyzed by fitting the experimental data to a simple equivalent circuit model. It was found that the equivalent circuit that fit the experimental data consists of one time constant model $R_{s}\left(R_{p} C_{d l}\right)$ for steel electrodes in $\mathrm{HCl}$ solutions as a given in Fig. 9. It includes the solution resistance $R_{s}$ and the double layer capacitance $C_{d l}$ which is 
placed in parallel to the polarization resistance $R_{p}$. The obtained Nyquist impedance diagrams in most cases does not show perfect semicircle, generally attributed to the frequency dispersion as a result of roughness and in homogenates of the electrode surface. The data reveal that, each impedance diagram consists of a large capacitive loop with low frequencies dispersion.

The results of simulation of all the measured impedance spectra for the carbon steel at different conditions as illustrated in Tables $5 \& 6$ reveal that, when mild steel is immersed in $0.1 \mathrm{M} \mathrm{HCl}$ aqueous solution containing 7 ppm CTAB, the polarization resistance $\left(\mathrm{R}_{\mathrm{p}}\right)$ and the double layer capacitance $\left(\mathrm{C}_{\mathrm{dI}}\right)$ (derived from Nyquist plots) are $114 \mathrm{ohm} \mathrm{cm}^{2}$ and $44 \mu \mathrm{F} \mathrm{cm}$, respectively. The impedance $\log (\mathrm{Z} / \Omega)$, value derived from bode plots is 3.3 . While, when mild steel is immersed in $0.5 \mathrm{M} \mathrm{HCl}$ aqueous solution containing $25 \mathrm{ppm}$ of CTAB, the $R_{p}$ is $44.8 \mathrm{ohm} \mathrm{cm}$ and the double layer capacitance $\left(C_{\mathrm{dI}}\right)$ is $47 \mu \mathrm{F} \mathrm{cm} \mathrm{cm}^{-2}$ and the impedance $\log (\mathrm{Z} / \Omega)$ value is 3 .

It can be seen that, as carbon steel immersed in aqueous solution $0.1 \mathrm{M} \mathrm{HCl}$ containing $7 \mathrm{ppm}$ of inhibitor the $\mathrm{R}_{\mathrm{s}}$ increases from 46.9 to $114 \mathrm{ohm} \mathrm{cm}^{2}$, the $\mathrm{C}_{\mathrm{dl}}$ value decreases from 1787 to $44 \mu \mathrm{F} \mathrm{cm} \mathrm{cm}^{-2}$ and the impedance value increases from 1.25 to 3.3. Moreover, it can be noticed that the same trend was obtained when carbon steel immersed in $0.5 \mathrm{M} \mathrm{HCl}$ aqueous solution containing $50 \mathrm{ppm}$ of inhibitor, the $R_{s}$ increases from 10 to $44.8 \mathrm{ohm} \mathrm{cm}{ }^{2}$, the $C_{d I}$ value decreases from 6302 to $47 \mu \mathrm{F}$ $\mathrm{cm}^{-2}$ and the impedance value increases from 0.7 to 3 . This indicates that the film formed on the metal surface due to the presence of inhibitor which lead to 5 the decrease in local dielectric constant and increase in thickness of the electrical double layer, suggests that CTAB act via adsorption at the metal/solution interface ${ }^{(24-26)}$.

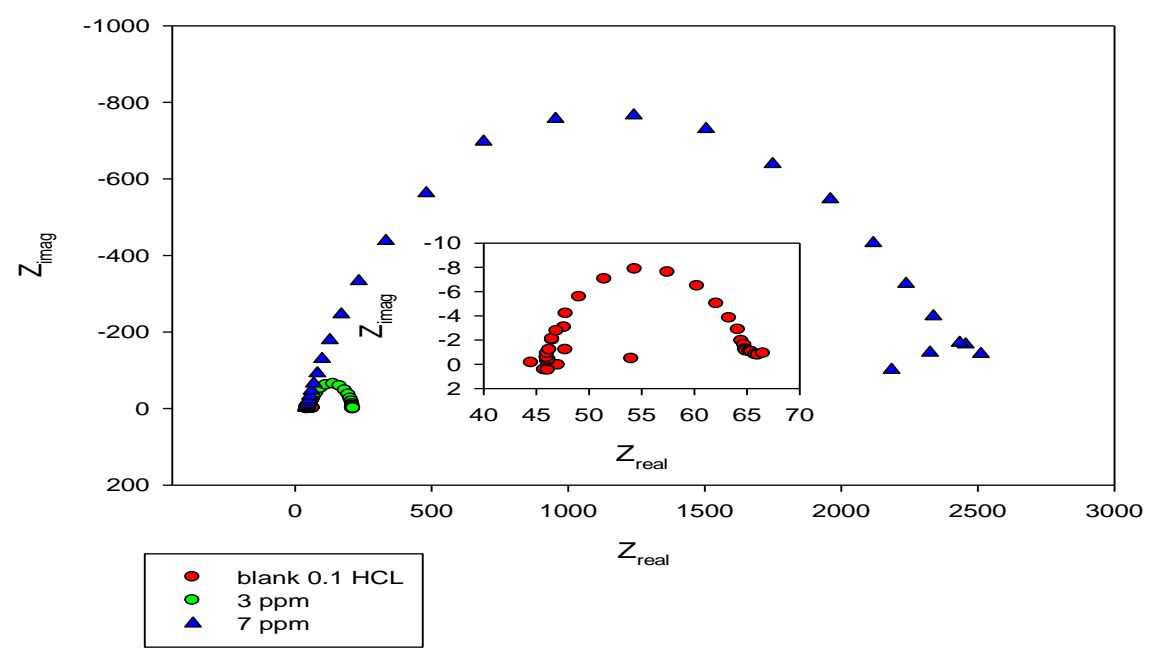

Fig. 5. Nyquist plots for carbon steel in $0.1 \mathrm{M} \mathrm{HCl}$ in the absence and presence of different concentrations of CTAB operated at the room temperature.

Egypt. J. Chem. 57, No. 5,6 (2014) 


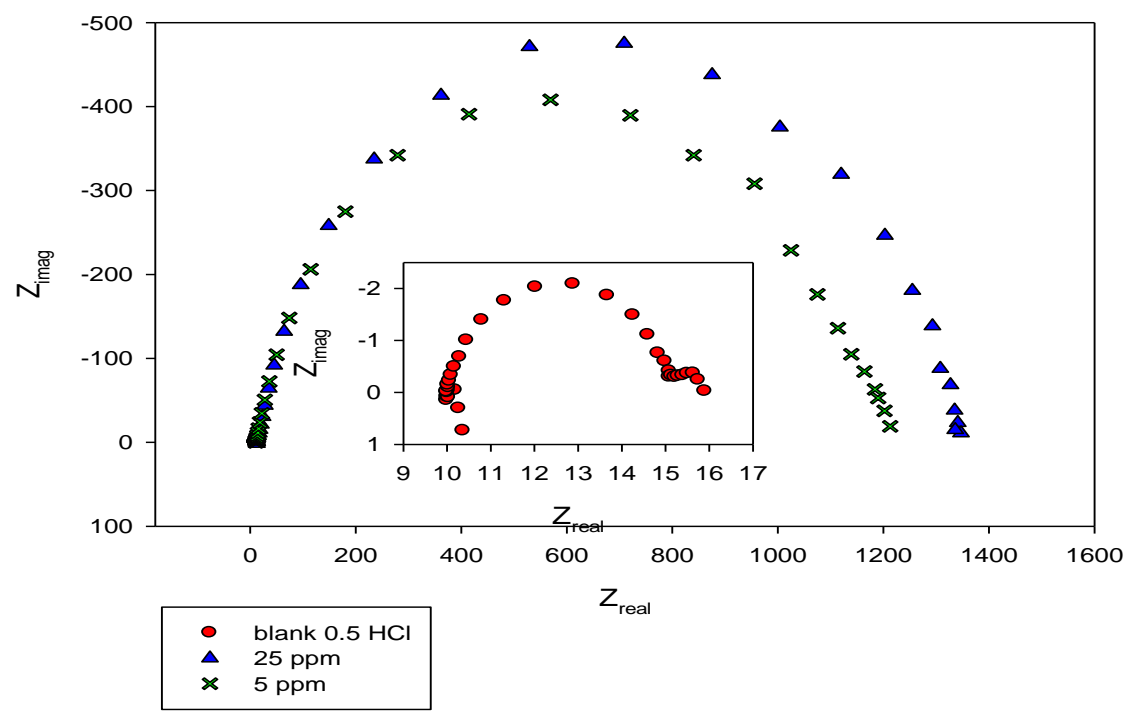

Fig. 6. Nyquist plots for carbon steel in $0.5 \mathrm{M} \mathrm{HCl}$ in the absence and presence of different concentrations of CTAB operated at the room temperature.

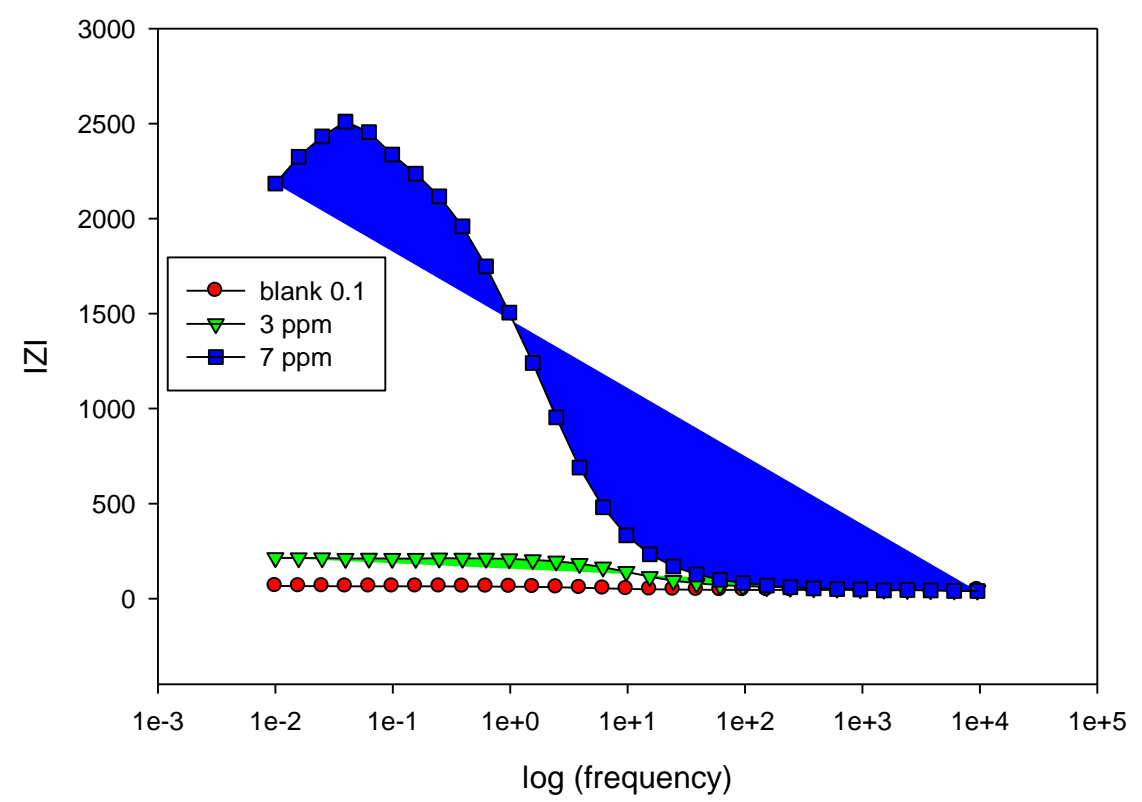

Fig. 7. Bode plots of $0.1 \mathrm{M} \mathrm{HCl}$ solutions containing CTAB.

Egypt. J. Chem. 57, No. 5,6 (2014) 


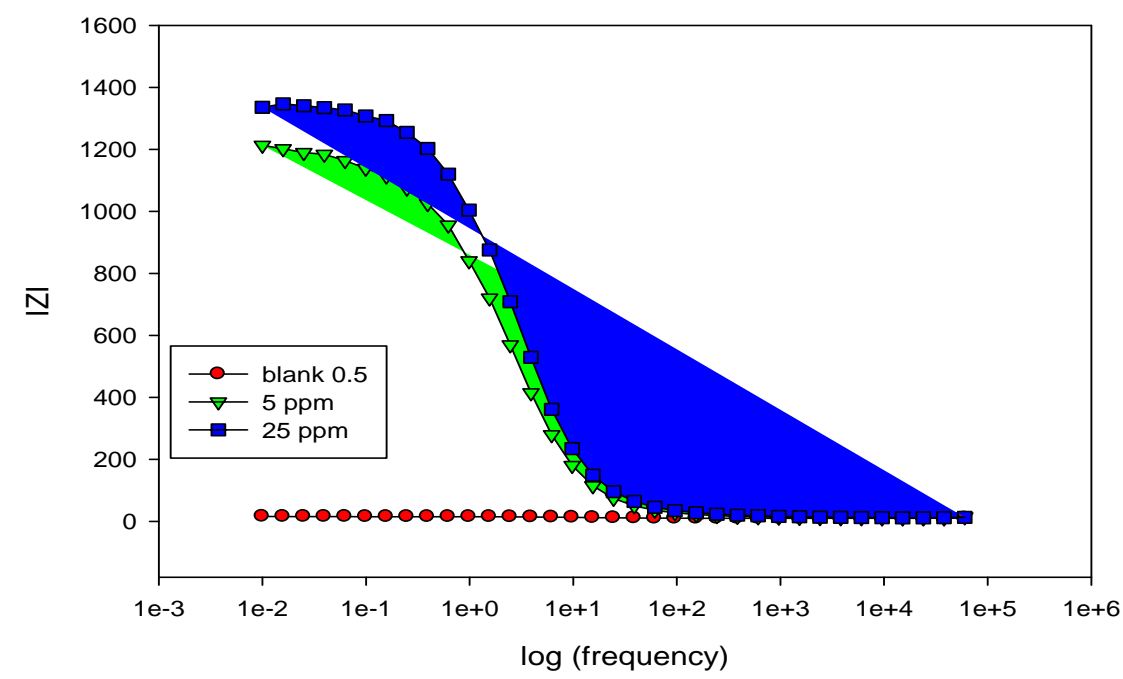

Fig. 8. Bode plots of $0.5 \mathrm{M} \mathrm{HCl}$ solutions containing CTAB inhibitor.

TABLE 5. Electrochemical kinetic parameters obtained from EIS technique for the corrosion of carbon steel in $0.1 \mathrm{HCl}$ at $\mathrm{CTAB}$ different concentrations operated at the room temperature.

\begin{tabular}{|c|c|c|c|c|c|c|}
\hline $\begin{array}{c}\text { Conc., } \\
\mathbf{p p m}\end{array}$ & $\begin{array}{c}\mathbf{C}_{\mathbf{d I}}, \boldsymbol{\mu} \mathbf{F} \\
\mathbf{c m}^{-2}\end{array}$ & $\begin{array}{c}\mathbf{R}_{\mathbf{s}} \mathbf{o h m} \\
\mathbf{c m}^{\mathbf{2}}\end{array}$ & $\begin{array}{c}\mathbf{R}_{\mathbf{c t}}, \mathbf{o h m} \\
\mathbf{c m}^{\mathbf{2}}\end{array}$ & $\begin{array}{c}\text { Impedance } \\
\mathbf{l o g}(\mathbf{Z} / \mathbf{\Omega})\end{array}$ & $\mathbf{I E} \%$ & $\mathbf{n} \%$ \\
\hline Blank & 1787 & 46.9 & 18 & 1.2 & & 0.9819 \\
\hline 3 ppm & 87 & 53.4 & 155.8 & 2.2 & 88.4 & 0.9841 \\
\hline 7 ppm & 44 & 114 & 2130 & 3.3 & 99.1 & 0.984 \\
\hline
\end{tabular}

TABLE 6. Electrochemical kinetic parameters obtained from EIS technique for the corrosion of carbon steel in $0.5 \mathrm{HCl}$ at $\mathrm{CTAB}$ different concentrations operated at the room temperature.

\begin{tabular}{|c|c|c|c|c|c|c|}
\hline $\begin{array}{c}\text { Conc., } \\
\mathbf{p p m}\end{array}$ & $\begin{array}{c}\mathbf{C}_{\mathbf{d I}}, \boldsymbol{\mu} \mathbf{F} \\
\mathbf{c m}^{-2}\end{array}$ & $\begin{array}{c}\mathbf{R}_{\mathbf{s}} \mathbf{o h m} \\
\mathbf{c m}^{\mathbf{2}}\end{array}$ & $\begin{array}{c}\mathbf{R}_{\mathbf{c t}}, \mathbf{o h m} \\
\mathbf{c m}^{\mathbf{2}}\end{array}$ & $\begin{array}{c}\text { Impedance } \\
\mathbf{l o g}(\mathbf{Z} / \mathbf{\Omega})\end{array}$ & $\mathbf{I E} \%$ & $\mathbf{n} \%$ \\
\hline Blank & 6302 & 10 & 5.1 & 0.7 & & 0.990 \\
\hline $5 \mathrm{ppm}$ & 63 & 40.3 & 1078 & 3 & 99.5 & 0.984 \\
\hline $25 \mathrm{ppm}$ & 47 & 44.8 & 1227 & 3.1 & 99.6 & 0.984 \\
\hline
\end{tabular}

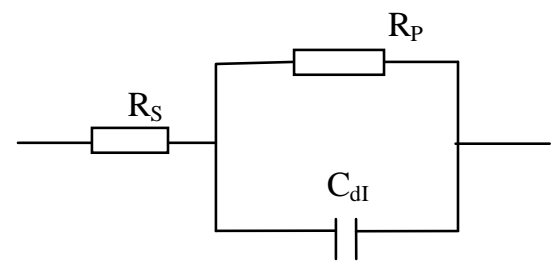

Fig. 9. The equivalent circuit model used to fit the experimental results.

Egypt. J. Chem. 57, No. 5,6 (2014) 


\section{Adsorption isotherms}

Basic information on the interaction between the inhibitors molecules and the carbon steel can be provided by the adsorption isotherm. Two main types of interaction can describe the adsorption of the organic compound: physical adsorption and chemical adsorption. These are influenced by the chemical structure of the inhibitor, the type of the electrolyte, the charge and nature of the metal. The surface coverage $\Theta$ of the metal surface by the adsorbed inhibitor was evaluated from weight loss measurement using the following ratio:

$$
\text { Surface Coverage }(\theta)=\mathrm{W}_{0}-\mathrm{W} / \mathrm{W}_{0}
$$

The Langmuir isotherm ${ }^{(27)}$ was found to provide the best description of the adsorption behavior.

$$
\mathrm{C} / \Theta=1 / \mathrm{K}+\mathrm{C}
$$

where $\mathrm{C}$ is the concentration of inhibitor and $\mathrm{K}$ is the adsorptive equilibrium constant. Plots of $\mathrm{C} / \Theta$ Vs $\mathrm{C}$ of 0.1 and $0.5 \mathrm{M} \mathrm{HCl}$ solutions yield a straight line as shown in Fig. 10. In both cases the linear regression coefficients $\left(\mathrm{R}^{2}\right)$ are almost equal to 1 and the slopes are very close to 1 , indicating that the adsorption of CTAB obeys the Langmuir isotherm and there is a negligible interaction between the adsorbed molecules. $K_{\mathrm{ads}}$ values can be calculated from the intercepts of the straight lines on the $\mathrm{C} / \Theta$-axis, the $\mathrm{K}_{\mathrm{ads}}$ is related to the standard free energy of adsorption, $\Delta \mathrm{G}_{\text {ads }}^{\circ}$ with the following equation:

$$
\Delta \mathrm{G}_{\mathrm{ads}}^{\mathrm{o}}=-\mathrm{RT} \operatorname{Ln}\left(C_{\mathrm{H} 2 \mathrm{O}} . \mathrm{K}_{\mathrm{ads}}\right)
$$

In equation (9), we use $C_{\mathrm{H} 2 \mathrm{O}}$ which is the molar concentration of water in solution in $\mathrm{g} / \mathrm{L}$ and $\mathrm{K}_{\mathrm{ads}}$ is the equilibrium constant of the inhibitor adsorption process, in $\mathrm{L} / \mathrm{g}$, the unity of $\Delta \mathrm{G}_{\text {ads }}^{\circ}$ depends only on the factor RT (kJ.mol ${ }^{-1}$ ). Thermodynamic parameters for adsorption process obtained from Langmuir's adsorption isotherm for the studied inhibitor are given in Tables7 and 8. 

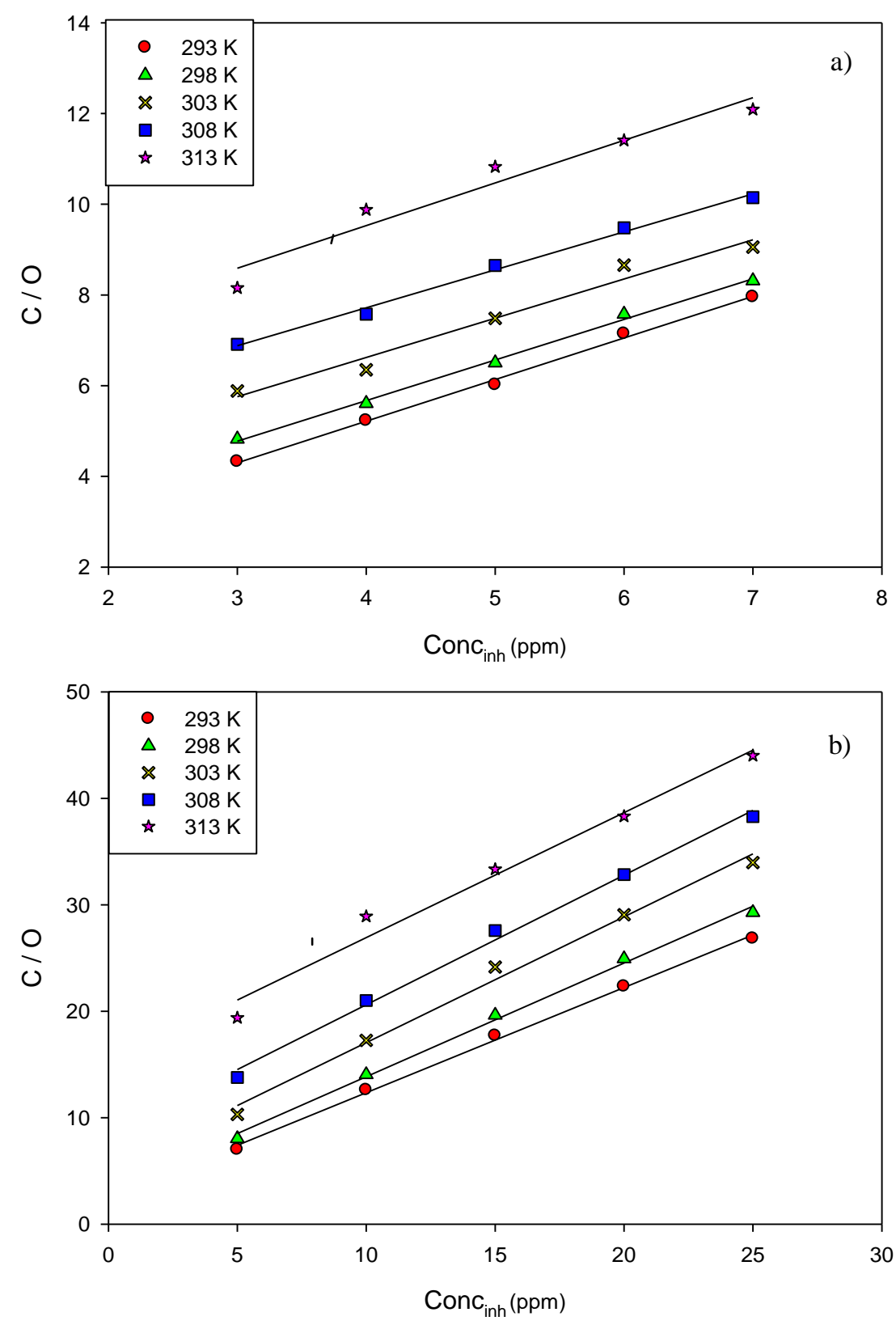

Fig. 10. Langmuir adsorption isotherm of CTAB on carbon steel surface in a) $0.1 \mathrm{M}$ $\mathrm{HCl}$ and b) $0.5 \mathrm{M} \mathrm{HCl}$ at different temperature.

Egypt. J. Chem. 57, No. 5,6 (2014) 
The negative $\Delta \mathrm{G}_{\text {ads }}^{\circ}$ values (Table 7 and 8 ) are consistent with the spontaneity of the adsorption process and the stability of the adsorbed layer on the carbon steel surface ${ }^{(28)}$. It generally accepted that the values of $\Delta \mathrm{G}_{\text {ads }}^{\circ}$ up to $-20 \mathrm{~kJ} \mathrm{~mol}^{-1}$, the types of adsorption were regarded as physical adsorption, the inhibition acts due to the electrostatic interaction between the charged molecules and the charged metal, while the values around $-40 \mathrm{~kJ} \mathrm{~mol}^{-1}$ or smaller, were seen as chemisorptions, which is due to the charge sharing or a transfer from the inhibitor molecules to the metal surface in a covalent bond ${ }^{(29,30)}$. The $\Delta G_{\text {ads }}^{\circ}$ values obtained in this study range from -31.4 to $-32.6 \mathrm{~kJ} \mathrm{~mol}^{-1}$ for $0.1 \mathrm{M} \mathrm{HCl}$ and from -30.6 to $-31.5 \mathrm{~kJ} \mathrm{~mol}^{-1}$ for $0.5 \mathrm{M} \mathrm{HCl}$. It suggested that the adsorption mechanism of the $\mathrm{CTAB}$ on carbon steel in $\mathrm{HCl}$ solution was typical of the two process physical adsorption and chemisorptions. The heat of adsorption $\Delta \mathrm{H}^{\circ}$ is obtained from the Van't Hoff's equation ${ }^{(31)}$ :

$$
\text { Ln } \mathrm{K}_{\mathrm{ads}}=-\frac{\Delta H}{R T}+\text { constant. }
$$

when $\ln K_{a d s}$ vs. $(1 / T)$ is plotted, the values of $\Delta H$ are obtained from the slope.

The negative sign of $\Delta \mathrm{H}_{\text {ads }}^{\circ}$ in 0.1 or $0.5 \mathrm{M} \mathrm{HCl}$ solution indicates that the adsorption of inhibitor molecule is an exothermic process. Generally, an exothermic adsorption process signifies either physic- or chemisorptions while endothermic process is attributeable unequivocally to chemisorptions ${ }^{(32)}$. Moreover, the entropy $(\Delta S)$ is obtained for a range of temperatures with the following equation.

$$
\Delta \mathrm{G}^{\circ}=\Delta \mathrm{H}_{\mathrm{ads}}^{\circ}-\mathrm{T} \Delta \mathrm{S}_{\mathrm{ads}}^{\circ}
$$

The negative values of $\Delta \mathrm{S}_{\text {ads }}$ may be explained in the following way: before the adsorption of inhibitors onto carbon steel surface, inhibitor molecules freely move in the bulk solution, but with the progress in the adsorption process, inhibitor molecules were orderly adsorbed onto carbon steel surface, and hence, the entropy decrease.

TABLE 7. Thermodynamic parameters for the adsorption of CTAB on low carbon

\begin{tabular}{|c|c|c|c|c|}
\hline $\mathbf{T}(\mathbf{K})$ & $K_{\text {ads }}(\mathbf{L} / \mathbf{g})$ & $\Delta G_{\text {ads }}^{\circ}\left(\mathrm{kJ} \mathrm{mol}^{-1}\right)$ & $\Delta \mathbf{H}_{\mathrm{ads}}^{0}\left(\mathrm{~kJ} \mathrm{~mol}^{-1}\right)$ & $\Delta \mathbf{S}_{\text {ads }}^{o}\left(K^{\prime} \mathrm{mol}^{-1} \mathrm{~K}^{-1}\right)$ \\
\hline 293 & 0.64766 & -32.6 & \multirow[t]{5}{*}{-51.4} & -0.0641 \\
\hline 298 & 0.4781 & -32.4 & & -0.0637 \\
\hline 303 & 0.31665 & -31.9 & & -0.0643 \\
\hline 308 & 0.2289 & -31.6 & & -0.0642 \\
\hline 313 & 0.17343 & -31.4 & & -0.0639 \\
\hline
\end{tabular}
steel surface in $0.1 \mathrm{M} \mathrm{HC1}$. 
TABLE 8. Thermodynamic parameters for the adsorption of CTAB on low carbon steel surface in $0.5 \mathrm{M} \mathrm{HC1}$.

\begin{tabular}{|c|c|c|c|c|}
\hline $\mathbf{T}(\mathbf{K})$ & $K_{\text {ads }}(L / g)$ & $\Delta G_{\text {ads }}^{\mathrm{o}}\left(\mathrm{kJ} \mathrm{mol}^{-1}\right)$ & $\Delta \mathbf{H}_{\mathrm{ads}}^{\mathrm{o}}\left(\mathbf{k J} \mathrm{mol}^{-1}\right)$ & $\Delta \mathbf{S}_{\text {ads }}^{\circ}\left(\mathrm{KJ} \mathrm{mol}^{-1} \mathrm{~K}^{-1}\right)$ \\
\hline 293 & 0.4053 & -31.5 & \multirow[t]{5}{*}{-70.1} & -0.1317 \\
\hline 298 & 0.3148 & -31.4 & & -0.1298 \\
\hline 303 & 0.1916 & -30.6 & & -0.1303 \\
\hline 308 & 0.1185 & -29.9 & & -0.1305 \\
\hline 313 & 0.06585 & -28.9 & & -0.1316 \\
\hline
\end{tabular}

\section{Conclusion}

The corrosion of low carbon steel in $0.1 \mathrm{M}$ and $0.5 \mathrm{M} \mathrm{HCl}$ is efficiently inhibited by CTAB.

The inhibition efficiency of CTAB increases with increase in inhibitor concentration.

The inhibitor showed maximum inhibition efficiency at $7 \mathrm{ppm}$ concentration in $0.1 \mathrm{M} \mathrm{HCl}$ and at $25 \mathrm{ppm}$ in $0.5 \mathrm{M} \mathrm{HCl}$. Langmuir adsorption isotherm and the impedance studies showed that CTAB inhibits through adsorption mechanism.

Potentiodynamic polarization reveals that CTAB acted as mixed-type predominantly cathodic inhibitor. $\mathrm{Br}-$ ion acts as an adsorption mediator for bonding the two positive partners, the metal surface and the positively charged ammonium compound. This gives rise to the formation of an adsorption composite film; this film acts as a barrier facing the corrosion process.

\section{References}

1. Bothi, R.P., Abdul, R.A., Hasnah, O. and Khalijah, A., Elucidation of the corrosion inhibition of mild steel in $1.0 \mathrm{M} \mathrm{HCl}$ by catechin monomers from commercial green tea extracts. Acta Phys. Chim. Sin. 26, 2171-76 (2010).

2. Hosseini, M., Ehteshamzadeh, M. and Shahrabi, T., Elucidation of the corrosion inhibition of mild steel in $1.0 \mathrm{M} \mathrm{HCl}$ by catechin monomers from commercial green tea extracts. Electrochim. Acta, 52, 3680-85 (2007).

3. Tavakoli, H., Shahrabi, T. and Hosseini, M., Elucidation of the corrosion inhibition of mild steel in $1.0 \mathrm{M} \mathrm{HCl}$ by catechin monomers from commercial green tea extracts. Mater. Chem. Phys. 109, 281-86 (2008).

4. Prabhu, R.A., Venkatesha, T.V., Shanbhag, A.V., Kulkarni, G.M. and Kalkhambkar, R.G. Elucidation of the corrosion inhibition of mild steel in $1.0 \mathrm{M} \mathrm{HCl}$ by Catechin Monomers from commercial green tea extracts. Corros. Sci. 50, 3356-62 (2008).

Egypt. J. Chem. 57, No. 5,6 (2014) 
5. Shukla, S.K. and Quraishi, M.A., Theoretical and electrochemical studies of metformin as corrosion inhibitor for mild steel in hydrochloric acid solution. J. Appl. Electrochem. 39,1517 (2009).

6. Shukla, S.K. and Quraishi, M.A., The effects of pharmaceutically active compound doxycycline on the corrosion of mild steel in hydrochloric acid solution. Corros. Sci. 51,1990 (2009).

7. Kern, P., Landolt, D. and Abboud, Y., Elucidation of the corrosion inhibition of mild steel in $1.0 \mathrm{M} \mathrm{HCl}$ by catechin monomers from commercial green tea extracts. J. Electrochem. Soc. 237, pp. B228-35 (2001).

8. Aldykewicz, A.J., Isaacs, H.S. and Davenport, A.J., Elucidation of the corrosion inhibition of mild steel in $1.0 \mathrm{M} \mathrm{HCl}$ by catechin monomers from commercial green tea extracts. J. Electrochem. Soc. 142, pp. 3342-50 (1995).

9. Mu“ ller: B. Electrochemical investigation of substituted aniline, melamine and formaldehyde based terpolymers as effective corrosion inhibitors for mild steel in $1 \mathrm{M}$ hydrochloric acid solution. React. Funct.Polym, 39, 165-77 (1999).

10. Hasanov, R., Sadikoglu, M. and Bilgic, S., Thermodynamic, chemical and electrochemical investigation of pandanus tectorius extract as corrosion inhibitor for steel in sulfuric acid solutions. Appl. Surf. Sci. 253, 3913-3921(2007).

11. Chetouani, A., Hammouti, B., Benhadda, T. and Daoudi, M., Inhibition of mild steel corrosion in $1 \mathrm{M}$ hydrochloric acid using (E)-(4-(4-methoxybenzylideneamino)-4H1,2,4-triazole-3,5-diyl) dimethanol (MBATD). Appl. Surf. Sci. 249, 375-385 (2005).

12. Bouklah, M., Hammouti, B., Lagrenee, M. and Bentiss, F., Thermodynamic properties of 2, 5-bis (4-methoxyphenyl)-1, 3, 4-oxadiazole as a corrosion inhibitor for mild steel in normal sulfuric acid medium. Corros. Sci. 48, 2831-2842 (2006).

13. Benabdellah, M., Touzani, R., Aouniti, A., Dafali, A., El-Kadiri, S., Hammouti, B. and Benkaddour, M., Inhibition efect of amoxycilin drug on the corosion of mild steel in $1 \mathrm{~N}$ hydrochloric acid solution. Mater.Chem. Phys. 105, 373-379 (2007).

14. Yildirim, A. and Cetin, M., Inhibition efect of amoxycilin drug on the corosion of mild steel in $1 \mathrm{~N}$ hydrochloric acid solution. Corros. Sci. 50, 155-165 (2008).

15. Khaled, K.F. and Al-Qahtani, M.M., Inhibition effect of amoxycilin drug on the corosion of mild steel in $1 \mathrm{~N}$ hydrochloric acid solution. Mater. Chem. Phys. 113, 150158 (2009).

16. Ma, H., Song, T., Sun, H. and Li, X., Inhibition efect of amoxycilin drug on the corosion of mild steel in 1N hydrochloric acid solution. Thin Solid Films, 516, 1020-1024 (2008).

17. Ju, H., Kai, Z.P. and Li, Y., Inhibition efect of Amoxycilin drug on the corosion of mild steel in $1 \mathrm{~N}$ hydrochloric acid solution. Corros. Sci. 50, 865-871(2008).

18. Trabanelli, G., In: F. Mansfeld (Ed.), Corrosion Mechanisms, Corrosion and Inhibition of $\mathrm{Cu}$-Zn Alloys in Acidic Medium by Using Isatin, Vol, 119, Marcel Dekker, New York, (1987) . 
19. Abdel Hamid, Z., Soror, T.Y., El-Dahan, H.A. and Omar, A.M.A., Evaluation of additives as corrosion inhibitors/antioxidants for high quality nano emulsifiable oils of metalworking fluids. Anti-corros.Meth.Mater. 45, 306-311 (1998).

20. Luo, H., Guan, Y.C. and Han, K.N., Corrosion inhibition of a mild steel by aniline and alkylamines in acidic solutions. Corrosion, 9, 54 (1998).

21. Bhardwaj, M. and Balasubramaniam, R., Corrosion Inhibition of mild steel in acid media by red peanut skin extract furfural resin. International journal of Hydrogen Energy, 33, 2178 (2008).

22. Ekanem, U.F, Umoren, S.A, Udousoro, I.I. and Udoh, A.P., Corrosion Inhibition of mild steel in acid media by red peanut skin extract furfural resin. Journal of Materials Science, 45, 5558 (2010).

23. Moretti, G., Quartarone, G., Tassan, A. and Zingoles, A., Electrochemical and thermodynamic investigation of some soluble terpolymers as effective corrosion inhibitors for mild steel in 1M hydrochloric acid solution. Electrochem. Acta, 411971 (1996).

24. Sathiyabama J., Susai Rajendran and Arokiaselvi J., Methyl orange as corrosion inhibitor for carbon steel in well water. Bull. Electrochemistry, 22, 363-370 (2006)].

25. Quraishi, M.A. and Rawat, J., Novel corrosion inhibition for carbon steel alloy: Synthesis and characterization. Mater. Chem. Phys. 70, 95 (2001).

26. Amin, M.A., El-Rehim, S.S.A., El-Sherbini, E.E.F. and Bayoumy, R.S., The inhibition of low carbon steel corrosion in hydrochloric acid solutions by succinic acid. Electrochimica. Acta, 52, 3588 (2007).

27. Agrawal, R. and Namboodhiri, T.K.G., Effect of iodide ions on corrosion inhibition of mild steel in $0.5 \mathrm{M} \mathrm{H} 2 \mathrm{SO} 4$ by Poly(4-vinylpyridine). Corros. Sci. 30, 37 (1990).

28. Popova, A., Sokolova, E., Raicheva, S. and Chritov, M., AC and DC study of the temperature effect on mild steel corrosion in acid media in the presence of benzimidazole derivatives. Corros. Sci. 45, 33 (2003).

29. Szlarska-Smialowska, Z. and Mankovwski, J., Crevice corrosion of stainless steels in sodium chloride solution. Corros. Sci. 18, 953 (1978).

30. Yurt, A., Ulutas, S. and Dal, H., Electrochemical and theoretical investigation on the corrosion of aluminium in acidic solution containing some Schiff base. Applied Surface Science, 253, 919-925 (2006).

31. Zhao, T.P. and Mu, G.N., The adsorption and corrosion inhibition of anion surfactants on aluminium surface in hydrochloric acid. Corros. Sci. 41, 1937-1944 (1999).

32. Donnely, B., Downie, T.C., Grzeskowiak, R., Hamburg, H.R. and Short, D., New mechanism synthesis of 1,4-benzothiazine and its inhibition performance on mild steel in hydrochloric acid. Corros. Sci. 18,109 (1978). 


\section{تثبيط تآكل الصلب الكريوني في محاليل حمض الهيدروكلوريك باستخدام أسيتيل ثلاثي مثيل بروميد الأمونيوم}

زينب عبدالحميد ، أماني محمد عطية" ، أحمد محمد هلال و و حلمي مجاهل

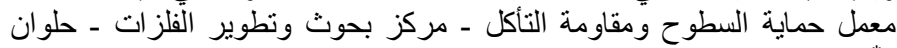

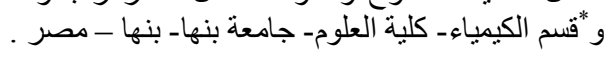

تقييم أسيتيل ثلاثي مثيل بروميد الأمونيوم (السيتاب) كمثبط لعملية تأكل الصلب

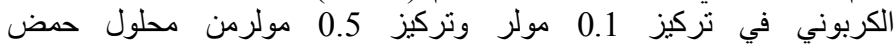
الهيدروكلوريك باستخدام عملية الفقد في الوزن وكئرني وعليتي الاستقطاب والمعاوقة

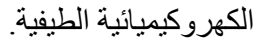

توضح النتئاج العملية ان كفاءة التثبيط تزداد مع زيادة تركيز السيتاب ولكن

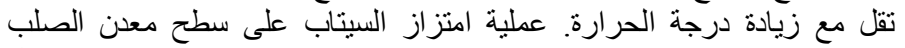

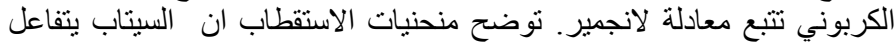

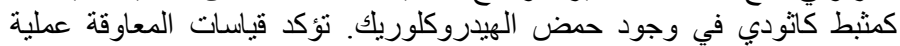

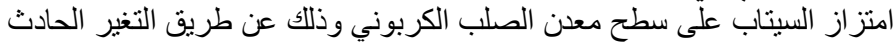

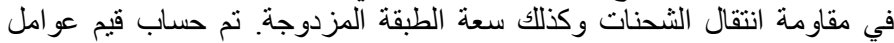

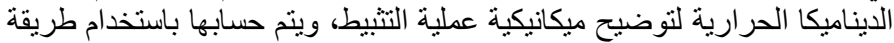

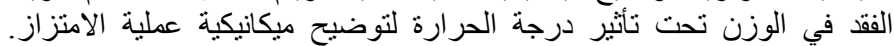

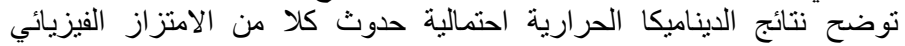
و الكيميائي للمثبط على سطح معدن الصلب الكربوني. 